\title{
Research of Organic Integration of College English and British \& American Literature based on Network Environment
}

\author{
Xiao Yue Y, a $^{\text {. }}$ \\ ${ }^{1}$ Jiangxi Institute of Economic Administrators, Nanchang, Jiangxi, 330088
}

Keywords: Network Environment, College English, Anglo- American Literature, Organic Integration

\begin{abstract}
In today's society, the continuous development of network technology, for college English and British \& American Literature, organic integration brings some advantages. However, there are still some schools do not make full use of the advantages of network development to improve the level of college students in English and the use of capacity. The existence of this phenomenon, there are many factors. The main reason is that schools and teachers are not fully aware of the important role of Anglo-American literature in learning college English. In this paper, the present situation of organic integration between college English and British \& American Literature is analyzed, and the corresponding suggestions are put forward for the related problems.
\end{abstract}

\section{Introduction}

English as the world's first communication language, by the majority of schools and learn the attention. From the beginning to learn English, many students through the English tutoring classes to improve their English culture. However, few people have noticed that Anglo-American literature is important for learning English. Learning English literature, not only can help students understand the Anglo-American culture, narrow cultural gap. But also can improve students' understanding of English language, and then improve the students' English culture and enhance students' ability to use English. Therefore, the organic integration of college English and Anglo-American literature is necessary.

\section{The Importance of Organic Integration between College English and British \& American Literature}

Today's society, many colleges and universities in English courses or follow the traditional teaching model, the teacher to teach the main oral, to remember a large number of vocabulary as the focus. This traditional teaching model often does not achieve higher English learning efficiency. If the college English and English aesthetics of the organic integration of teaching methods, not only can increase students' understanding of Anglo-American history and culture, but also can improve students' ability to understand English and the ability to use, so as to improve students' learning efficiency. Therefore, in the rapid development of network technology environment, the school can use the new media technology, so that college English and British \& American Literature organic integration.

\section{Anglo - American literature on the Role of Learning English}

Only in a certain environment, students can use their own knowledge of the language to communicate with others. Nowadays, the English teaching in colleges and universities does not pay much attention to the cultivation of students' oral English. However, students are limited by the scheduled scene and are not free to play. However, Anglo-American literature involves a wide range of knowledge, the British \& American Literature cited to the English classroom, to enrich the students' English knowledge structure, but also for students to create a good language exchange environment. Students through a number of practice, you can improve their ability to use English and oral English proficiency.

The relationship between culture and language is inseparable. Culture has a necessary connection 
to the development of language, the language reflects a place of culture, social development and other aspects. English and Chinese are two completely different languages, there will be some cultural differences. Through the Anglo-American literature, students can learn more about Anglo-American culture, appreciate the connotation of Anglo-American culture, narrow the cultural differences encountered in the learning process, broaden the students 'cultural horizons, and enrich the students' English cultural knowledge.

Character determines a person and the outside world of communication, emotional decision of a person's thinking ability. Many people say that entering the university is like entering half the community. University, each person different personality, learning efficiency and learning style is naturally different. Some people learn high efficiency, some people learn inefficient. Therefore, different people learn the effect is different. However, in the university is a self-learning environment, teachers in the teaching process which can not take into account every scholar. However, the combination of British \& American Literature and college English, allows students to find the fun of learning, improve the enthusiasm of students, enhance students' self-confidence in the classroom bravely communicate with their teachers

\section{The Status Quo of Fusion between College English and British \& American Literature}

Many schools and English teachers are not fully aware of the important role of British \& American Literature for college English, giving British \& American Literature do not attach importance to the attitude. Follow the traditional teaching mode, according to the textbook text taught oral knowledge of English, focusing on vocabulary and English grammar, emphasizing the importance of students to master a large number of vocabulary, and will not pay attention to the students' ability to self-learning and oral English proficiency. There are some teaching experience but older teachers, for the new network of media technology do not understand, naturally it will not be applied to the course to go [1]. Therefore, college English and British \& American Literature can not be a good fusion.

Although the current rapid development of network technology, but some schools still exist in the British \& American Literature teaching equipment situation. English teachers can not use the network technology in the classroom, the college English and British \& American Literature organic combination. Students in the classroom did not realize that Anglo-American literature to study college English has a huge role, extra-curricular time will not take the initiative to learn through the network platform Anglo-American literature.

Most colleges and universities use the traditional examination system, only pay attention to students master the English knowledge, and will not pay attention to the ability of students to apply for the assessment of English. For the student's final grade statistics, only the score on the student's face is taken. It leds to college students and learn English only to test four or six, so as to find a good job. Just think that learning English is to get a satisfactory result, did not realize that learning English can also exercise their ability to think, to learn other subjects have some help. The The English examination system has seriously affected the initiative and enthusiasm of college students to learn English, which leads to the inability of students to fully understand the importance of British \& American Literature.

\section{Promote College English and British \& American Literature Organic Integration Measures}

The learning atmosphere has an important influence on the students' enthusiasm for learning and learning efficiency. Therefore, teachers should lead students to create a good learning atmosphere. Change the traditional oral teaching mode, so that students participate in the teaching link to them, to create an active learning atmosphere, improve student learning efficiency. Teachers can also be in the process of teaching, the use of multimedia technology to learn to play video, pictures, etc., rich teaching methods also help students learn more English knowledge. Teachers also need to quote British \& American Literature into the classroom, so that students get a certain understanding of Anglo-American literature, appreciate the great charm of Anglo-American literature. And to 
recommend some of the students to learn English and improve the level of English has a great role in the British \& American Literature, so that students in English in the classroom to express their own reading.

The rapid development of new media media technology has brought some advantages to the reform of education, teachers should make full use of this advantage to improve their level of education and student learning efficiency. Therefore, teachers can apply the new network of media technology to the classroom, so that college English and British \& American Literature organic integration. Through the network platform, not only to provide their own rich teaching materials, but also to break the traditional scheduled situation restrictions, students can free oral practice, but also allows students from the Anglo-American literature to find their own content of interest to learn.

After the corresponding reform of the teaching methods, the examination system to be a certain degree of innovation is necessary. Only to change the traditional examination system, in order to better reflect the new teaching methods. Adjust the students' English ending results of the composition, the British \& American Literature test scores into them. The contents of the essay should be related to the feelings of reading British \& American Literature. There is no scenario limit, and students can play freely at the scene. Through the reform of the examination system, students can change the learning style, improve the enthusiasm of students to learn, take the initiative to invest in British \& American Literature, and then achieve the organic integration of college English and Anglo-American literature effect.

In the teaching process of organic integration between college English and British \& American Literature, teachers can set up discussion groups in class. Each group has a different discussion topic, students are free to discuss [1]. To the time of the discussion, each group to send a representative came to power to announce their own discussions. Through the establishment of the discussion group, we can strengthen students' understanding of Anglo - American literature and improve the enthusiasm of students. Teachers for students to discuss the results of the discussion to explain, can help students better understand the knowledge of British \& American Literature. Through the discussion group, students discuss the problems encountered in learning Anglo-American literature and discuss with their own team members, so that their English level in the discussion and analysis of the process which has been greatly improved.

\section{Conclusion}

In short, Anglo-American literature has a great advantage in improving students' English proficiency. Therefore, both English majors and non-English majors should pay attention to the study of Anglo-American literature. Teachers should use the network technology to bring the contents of Anglo-American literature into the classroom; students should take the initiative to apply the network platform to learn Anglo-American literature. Only through the joint efforts of teachers and students, can the university English and British \& American Literature organic integration. College English and British \& American Literature to achieve a good fusion effect, the students' English level will naturally is a corresponding increase.

\section{References}

[1] Yang Huiyong. Evaluation of College English and Anglo - American Literature in Network Environment [J].Journal of Shandong Agricultural Engineering Institute, 2015,09: 151-152.

[2] Tai Qian. Analysis of the Effective Integration of College English and Anglo-American Literature in the Network Environment [J]. Journal of Jilin Teachers College of Engineering and Technology, 2014, 10: 91-92. 